\title{
Analysis on the Effect of Family Consumption Psychology on the Economic Demand Structure under the Background of the Financial Crisis
}

\author{
Ji Zeng \\ Sichuan University of Science \& Engineering, \\ Zigong 643000, Sichuan
}

\begin{abstract}
As is known to all, the global financial crisis produces tremendous negative impacts on the economy progress and development of all countries. In order to change the situation and promote a more stable economic development, the targeted fiscal policy is adopted in all countries to stimulate the economy. For China, the key is to actively expand domestic demands and effectively transform the economic demand structure, aiming to secure a stable and rapid economic development. In addition, the overall level of the economic growth of a country is reflected from its consumption level, of which the most important thing is the volume of consumption. Consumer psychology plays a decisive effect on the volume of consumption. Consumer psychology, therefore, plays a role in China's economic demand structure and growth level when affecting the volume of consumption. In the social final consumption, household consumption occupies an important position, and therefore, the family psychological consciousness is also very important to affect the national economic demand structure.
\end{abstract}

Keywords- Financial Crisis; Household Consumption Psychology; Economic Demand Structure; Effect; Analysis

\section{Introduction}

In recent years, China's economic development has been accelerated, so that the people's quality of life has improved. Under the effect of the global financial crisis, however, it is necessary to actively improve the economic demand structure in order to guarantee the stable economic development. In this paper, the characteristics of the family consumption psychology and its effect on the economic demand structure are comprehensively analyzed. Under the background of the financial crisis, the effect of family consumption psychology on the national economic demand structure is analyzed, expecting the effect to react on the family consumption psychology and promote family consumption ideas and ways to transform. The important purpose of expanding the domestic demand is to ensure the stability and rapid development of the national economy.

2. The importance of family consumption psychology to the study of economic demand structure

To promote the country's economic growth, it is necessary to stimulate the domestic consumption and continuously expand domestic investment and foreign trade exports. This is related to the important role of the "troika" [1]. Under the background of the rapid social and economic development, a serious impact is exerted by the financial crisis, but the lives of residents in China are always in the rising stage, especially the urban residents living quality and level. The effects of the financial crisis and the effect of China's rapid development of economy form the current economic environment. On the one hand, a severe test is brought for people. On the other hand, opportunity and hope are produced. Under this situation, the family consumption psychology has changed and presented new characteristics. That is to say, brand-new family consumption psychology plays a more and more important role in China's economic demand structure. Therefore, in the process of researching 
China's economic demand structure, the changes of family consumption psychology play an important role and are necessarily emphasized to some extent.

\section{Analysis on the consumer psychology of families receiving low and middle income}

At the present stage, China has entered the period of the population aging; the increasing number of only child is growing, thus producing high pressure on the young people. It thus appears that the families receiving low and middle income will not overspend other aspects of consumption except the daily necessities. In addition, the idea of "those who do not plan for the future will find trouble at their doorstep" has always been maintained in China, and therefore, most families will be more pessimistic about the future economic development and the stability of the family income according to their expectations. However, there are many factors to affect the family consumption psychology, mainly including the actual family economic income, family decision-makers' preference, and price level and so on. In the above factors, the economic income level plays a decisive role. In the present stage, the low and middle income families' awareness of consumption is very cautious, and most people live frugally and put the saved money in bank deposit to provide the corresponding emergency funds. The survey of the actual situation shows that in the shopping mall or supermarket sales promotions, more than $80 \%$ of the respondents thought that they would not adjust the daily expenses because of these promotional activities; in these consumers, more than half of them would reduce consumption for saving the daily spending because of the economic recession; the rest of the respondents would choose to buy more because of the commodity price reduction, and $8 \%$ of them would choose to withdraw money for consumption [2].

But a phenomenon opposite to the real consumption is that the consumption of the low and middle income families continues to grow in housing and insurance. From the perspective of the aspect of the demand for housing, the low and middle income families could afford to buy commodity houses and economy applicable rooms, but they are more willing to invest the money into the purchase of housing under the influence of the traditional ideas. At the beginning of this century, the area of China's commercial housing sales exceeded 320 million square meters, an increase of nearly 10 times of that in the 1990s. Therefore, its growth speed was very fast. As the urbanization process is deepening and the people's daily life standard is rapidly improving in China, the demand for housing is rapidly increasing.

\section{Analysis on the consumer psychology of families receiving higher income}

Families receiving higher income are satisfied with the material life, so they need to improve the actual quality of life using the remaining money on the basis of daily life and long-term investment consumption. Families can transfer the consumption center to the consumption center or the others under the condition that they are satisfied with the physical demands, but this condition is fulfilled in the families receiving higher income.

According to international experience analysis, the per capita GDP had risen to $\$ 800-\$ 1000$, so that the tourism consumption was promoted to enter the period of rapid growth, and this phenomenon was is increasingly prominent in China [3]. Therefore, China's tourism market also appears development and prosperity, in which family tour has become a growth point of the tourism consumption. Meanwhile, the consumer services from tourism companies are diversified; holiday seasons also bring an opportunity for family tours. This type of families lives in urban areas usually, but traffic and industries have rapidly developed along with the further urbanization process and then serious pollutions such as air pollution, water quality 
decline, more living garbage, and severe traffic noise are caused, thus making the living environment seriously deteriorated.

The actual survey data in recent years shows that China has become the focused country of the automobile consumption, but also the third largest automobile consumer market. On the basis of the rapid social and economic development, family incomes are obviously increasing. Therefore, most families will focus on improving living standards and effectively increase the quality of their lives on the premising of getting satisfied with every aspect, while automobile consumption is one of the most optimal choices. China is a populous country, and its economic strength is also rapidly increasing, so the potential of its auto consumption market is great [4].

\section{The transformation of family consumption psychology}

In China, the development of science and technology is accelerating along with the development of the social productivity in China; the updates are especially faster. On this basis, the social competition is more intense, so the self-knowledge quality and cultural literacy are necessarily improved in order to meet the economic development needs. A society will inevitably be eliminated if it is always in stagnation, and therefore, people must enhance the demand for knowledge. In this background, more families will put consumption psychology on educational investment. The investment in both family policymaker education and children's education begins to rapidly increase. The education consumption in positively improving the quality of the family members gradually becomes the focus of family consumption, but also grows into the future key development direction in the family consumption psychology. It will be gradually highlighted in the process of social development. Meanwhile, the proportion of the realistic education consumption increases gradually and also more family savings will also be used in the education consumption, according to the analysis of the low and middle family consumption psychology. With the transformation of the family consumption psychology, more attention is paid to educational consumption, thus not only effectively meeting the growing material and cultural needs of family members, but also playing an effect on the national economic demand structure.

In recent years, the development strategy of building a harmonious socialist society has been raised in China, so the family consumption psychology is gradually turned to the people-oriented development direction and focused by more people. The rapid development of the society promotes health care, culture and education, and communications to get greater development advantages; the enjoyment-oriented consumption is increasing rapidly and so is its share. As high-end electronic products such as computers and cell phones are popularized and the automobile consumption becomes common, traffic and communication also gradually become the new bright spots in family consumption. Thus, the consumer psychology of low, middle and high income families will change in the process of social development [5]. Under the background of the rapid development of science and technology, the competition is increasingly fierce, and therefore, the family consumption psychology begins to develop toward services and development consumption, and then, the proportions of the two types of consumption are rising without a stop.

\section{Conclusion}

In this paper, family consumption psychology is comprehensively, specifically analyzed and studied. Low and middle income families keep very cautious to consumption and obviously desire to save money, but their consumption demand for children's education, endowment insurance and housing is higher. In the higher income families, the consumer psychology is gradually developing toward enjoyment and 
forming a new bright consumption point. Family consumption psychology, however, always changes along with the social and economic transformation. Also, the transformation of family consumption psychology and the increase of the development and service oriented consumptions are emphatically introduced; the important effects of family consumption psychology on the economic demand structure are studied under the background of the financial crisis, so as to further improve the national economic demand structure and promote the further development of the national economy. This study is of certain practical significance, and therefore, it still needs to study in depth.

\section{References}

[1] Xinyin Jiang. The Effect of Household Consumption Psychology on the Economic Demand Structure under the Financial Crisis
[J]. Science and Technology and Enterprises, 2012 (9): 266-267.

[2] Jinfang Tian, Qianqian Zhu. Empirical Interpretation on the Effect of Consumer Confidence on Chinese Household Consumption [J]. Journal of Economics and Management Review, 2013 (2): 76-81.

[3] Xinyin Jiang. The Effect of Boosting Domestic Demand Policy on Family Consumption Psychology under the Financial Crisis [J]. Science and technology of China, 2012 (8): 233-234.

[4] Liangjie Song. Analysis on the Residential Consumption Model Affecting Factors under the Financial Crisis [J]. Journal of the Commercial Age, 2010 (35): 27 28.

[5] Xinyin Jiang. The Main Effect of the Financial Crisis on the Family Consumer Psychology [J]. Science and Technology Entrepreneurs, 2012 (1): 194-195. 